NOTAS

\title{
¿CÓMO SE RELACIONAN LOS MARINEROS DE AGUAS VIRTUALES?
}

Guadalupe Chabaud*

\section{Fenómenos como el Titanic no surgieron de la nada}

Para evaluar la influencia de lo visual en las relaciones interpersonales que se dan a raíz del nacimiento de Internet, surge la inevitable necesidad de hablar sobre la televisión. Con el advenimiento de este medio, dice Sartori, ${ }^{1}$ la imagen obtuvo supremacía sobre la palabra: “en el principio fue la imagen y, con ella, la palabra fue destronada”. Inventos como la imprenta, el telégrafo, el teléfono e incluso la radio rendían pleitesía a su majestad el verbo: todos dependían de la palabra. Sin duda alguna, era el ser humano quien creaba distintos tipos de medios con el objeto de progresar y de hacer más

* Centro de Lenguas, ITAM.

${ }^{1}$ Sartori Giovanni, Homo Videns. La sociedad teledirigida, 1998, SantillanaTaurus, p. 37. cómodo y comunicado su quehacer cotidiano; sin embargo, son varios los autores que como Sartori afirman que, con la aparición de la televisión, fue el medio el que creó una nueva especie de ser humano. "Nunca el ser humano que juega u homo ludens se sintió más satisfecho y emocionado que con la aparición de la televisión: medio espectáculo por excelencia.” El Midas de los mass media fue capaz, según la opinión de Umberto Eco, ${ }^{3}$ de esclavizar a la prensa y de convertir en pan y circo tanto a la política como a la religión. Por otro lado, debo agregar, nunca los padres de familia se sintieron tan felices al contar con los servicios 'gratuitos' de tan sui generis nana electrónica: nadie antes pudo apaciguar, durante tanto tiempo (6 horas promedio diarias), a las

\footnotetext{
${ }^{2}$ Ibid., p. 36.

${ }^{3}$ Eco Umberto, Cinco escritos morales, sobre la prensa, 1998, Lumen, p. 78.
} 
'fieras del hogar' (léase niños de la casa).

A la televisión se le atribuye la creación de un niño 'video-formado' u homo videns que ha perdido la capacidad simbólica; que es incapaz, por otro lado, de hacer abstracciones y de conceptuar; que ha dejado, asimismo, de creer y de pensar para sentir. ${ }^{4}$ Por último, es un niño que pasa seis horas diarias promedio frente al televisor (UNESCO, 2001).

En la opinión de estos mismos autores, ${ }^{5}$ "en la cultura audiovisual, aunque moderna y atractiva, subyacen riesgos y peligros evidentes como el hecho de empachar al niño con millones de imágenes antes de que aprenda a leer y a escribir; de convertirlo en adicto crónico de los video juegos; de adormecerlo, aislarlo y predisponerlo a aburrirse en la escuela. Al ser cuantitativa, fragmentaria y pobre, produce en el menor una atrofia cultural”.

En este tenor, nadie puede negar que el poder de la imagen es evidente, puesto que todo lo cambia, todo lo transforma: "non vidi, ergo non est: lo que no se ve no es”. La universalidad, alcance y penetración de este tipo de lenguaje no tiene límites, no conoce fronteras.

La imagen seduce y enamora: no hay nada más atractivo que una bella

${ }^{4}$ Ibid., p. 37.

${ }^{5}$ Ibid. imagen; sin embargo, esta seducción, este enamoramiento se basan sólo en la apariencia, en aquello que se ve; difícilmente el ser humano toma en cuenta el interior; rara vez se toma la molestia, como Dalí, de levantar la piel del mar para descubrir qué hay dentro de él. Fomenta entre las personas las relaciones narcisistas o de imagen en las que sólo cuenta lo exterior y la apariencia. En este sentido, se puede ser proclive a sostener relaciones vanas y superficiales basadas sólo en lo que se ve: la cara bonita, la nariz respingada, el color del cabello o el pantalón de moda.

Hay, por otro lado, quienes prefieren ver cómo viven otros que vivir y éste es el argumento que apuntala el éxito de programas como los talk shows y como el de Big Brother. Cuando se da este fenómeno psicológico, cuando las personas prefieren lo virtual, se conforman con las imágenes y dejan de interesarse por la realidad, se afirma, con cierta razón, que la televisión aísla y distorsiona el sentido y esencia de la relación interpersonal, cara a cara. Por ello, ante el surgimiento de medios visuales como la televisión y frente a la innegable supremacía de lo visual sobre lo escrito, surgen la preocupación y la duda de poder conciliar la naturaleza y los intereses del hombre que piensa con los del hombre que 
NOTAS

ve y, por supuesto, la forma en que uno y otro se relacionan con los demás. Para algunos, es imposible lograr dicha armonía que enfrenta en encarnizada competencia al homo sapiens contra el homo videns.

Se dice, no obstante, que el homo videns, cansado del aislamiento y la pasividad; de tanto descansar y divertirse, creó la Internet, Red de redes y, con ella, un nuevo tipo de imágenes: las imágenes virtuales. Internet surge, pues, como propuesta bien intencionada para armonizar en un multimedia la imagen y la palabra. El ser humano creó con ella la posibilidad de relacionarse virtualmente con sus semejantes.

\section{Internet y el botamiento de un moderno Titanic}

Con la aparición de Internet, se izaron nuevas velas y se abrió paso a una nueva especie de marinero o cibernauta: navegante activo que se lanza ilusionado día con día a la conquista de un océano vasto en imágenes y en textos escritos. Ignacio Ramonet opina, por otro lado, que "los ordenadores son gregarios como los humanos y que Internet es la red más sociable del planeta". ${ }^{6}$ Aventurarse,

${ }^{6}$ Ramonet Ignacio, Un mundo sin rumbo, 1999, Problemas de la Civilización Contemporánea I, volumen II, Departa- pues, en estas aguas supuestamente ofrece a cada tripulante la posibilidad de dialogar e interactuar, desde su camarote, con otros cibernautas. (iं)

Me aventuro sin rumbo en un mar continuo de luz e imágenes fragmentadas que me embriagan. Navego mar adentro y no puedo detenerme. Ahogado en una avalancha infinita de mensajes no puedo tocar tierra, llegar a puerto. Durante la travesía, compro, vendo, me informo, me enamoro. Sé que muchos navegan junto a mí, pero no puedo establecer relación con ninguno desde mi camarote. Muchas voces me instan a saltar y a abandonar el barco. Al amanecer, despeinado y ojeroso, sin despojarme de la pijama, vuelvo a zarpar.

Si la sucesión de imágenes en la televisión es veloz y fragmentaria, en la Red la fragmentación es infinita y avasalladora: páginas, pestañas, links o vínculos; nuevas páginas, más pestañas y nuevos links. Sucesión ilimitada y enloquecedora que impiden tocar tierra y llegar a puerto.

La avalancha de imágenes, sirenas seductoras que susurran infinidad de mensajes al oído del marinero, pueden hacer que éste pierda el sentido y mento Académico de Estudios Generales, ITAM, p. 231. 
provocar así el extravío de la embarcación. Se navega sin cesar, pero sin rumbo.

Sólo se salvarán del naufragio, dice Sartori, los marinos experimentados: verdaderos estudiosos que seguirán leyendo libros y que surcarán las aguas de la red para complementar datos, establecer vínculos (links) de investigación o encontrar nueva bibliografía.

El cibernauta promedio, en opinión de Sartori, video-formado y reblandecido por la televisión, matará su tiempo libre en compañía de 'almas gemelas' deportivas, eróticas o de pequeños hobbies. Corre el riesgo de ser seducido, de perder el control y de caer irremediablemente en la tecnoadicción.

Echen campanas al vuelo, la fe despierta temprano.

Cansado de sus celos, harto de su obsesión, la abandoné con el alba. Cantó el gallo, como nunca, cantó tres veces, la aurora sabe de estas cosas.

Son las nueve, pasan de las once, no aguanto más.

Camino de prisa, me cuesta trabajo pensar.

El sudor, que empapa mi frente, cede el asiento al afán.

Clavo la vista en la nada, mis ojos se ciegan de mirar.
Desesperado, en estado de delirio, permito que la Red me vuelva a atrapar.

"La cibernavegación es muy visual y visualizada. En las llamadas imágenes virtuales o simuladas, hay una infinita descomposición o recomposición que el cibernauta individualiza y hace suya.” (G. Sartori)

Si el cibernauta promedio no toma en serio la navegación y la ve como un simple videojuego, corre el riesgo de sucumbir ante la seducción de las imágenes simuladas y perderá el sentido de la realidad; de los límites entre lo verdadero y lo falseado. La imagen impone su poder y autoridad: "el ojo cree lo que ve; le parece real. Lo que no ve no existe; lo que ve es verdadero".

"No tengo que tener un auténtico cuerpo ni comida auténtica para comer; no necesito disponer de una auténtica silla para sentarme. No necesito tampoco ninguna de las cosas que la gente necesita para hacer el amor. Hicimos lo que hicimos con finura y devoción; con una gran alegría. Claro que era simulado, pero la sensación era exactamente la misma. Cuando terminamos, mi corazón simulado latía un poco más aprisa, y mi simulado aliento jadeaba ligeramente, y rodeé con mis simulados brazos a mi amor y la apreté contra mí para empaparme en su 
NOTAS

simulado olor y sentir su simulado calor."7

Al navegar, nacerá en este tipo de navegante promedio un sentimiento profundo de alienación y frustración que hará que la embarcación encalle justo en la orilla opuesta: aun antes de terminar la travesía, estos eternos soñadores, que surcan los mares de la ficción y de mundos imaginarios, habrán emprendido solos un nuevo viaje fantástico.

Ignacio Ramonet afirma que "las interacciones en la red son un pálido substituto de las relaciones cara a cara; intercambiar mensajes mediante un ordenador nos deja siempre solos frente a un teclado". ${ }^{8}$

Me aterra haberme quedado solo, otra vez, frente al teclado de la computadora.

La realidad se perdió, la dejé en la otra orilla.

He dejado de necesitar de los demás; los demás han dejado de necesitarme.

Ciego de luz, sumido en la más profunda obscuridad, espero a que la luna salga.

Los chats o charlas entre cibernautas curiosamente carecen de imagen; esto, por un lado, convierte la

${ }^{7}$ Pohl Frederick, Los anales de los Heeches, 1988, Ultramar, p. 173.

${ }^{8}$ Ibid., p. 234. práctica en un riesgo porque el cibernauta no sabe si la mujer con quien habla es realmente una mujer o si se está compartiendo información íntima con alguien que va a hacer mal uso de ella; sin embargo, el hecho de no estar cara a cara, desinhibe muchas veces al navegante y lo fuerza a ser más descriptivo, más comunicativo en su conversación.

Si bien el usuario del correo electrónico utiliza más bien palabras para comunicarse, la red ofrece al video-marinero bancos con infinidad de imágenes para ser enviadas en lugar de los mensajes escritos. Es común abrir un correo y encontrar, por ejemplo, la imagen de un globo rojo que crece, crece y crece hasta explotar. Al explotar, aparece un letrero que dice: ¡Hola! o ¡Felicidades! La imagen lo dice todo; la imagen es, en este caso, más importante que las palabras.

\section{La voluntad: timón y brújula de cualquier embarcación}

De niño, el ser humano aprende a leer y a escribir; se le enseña, asimismo, a utilizar, poco a poco, con cautela, herramientas como el cuchillo o las tijeras. La imagen y la palabra, lenguajes autónomos ricos en símbolos, requieren también de un aprendizaje. Padres y maestros cuidan, con cierto 
esmero, la enseñanza de la palabra y se olvidan o subestiman la enseñanza, interpretación y buen uso de las imágenes. Los medios escritos y los electrónicos, incluyendo a la televisión y al mini-ordenador, ofrecen al ser humano un sinfín de posibilidades prácticas para facilitar su devenir cotidiano y oportunidades invaluables para desarrollarse y crecer personal y culturalmente. Su aparición como tal no implica progreso y crecimiento; el progreso está en función del uso adecuado y medido que el ser humano haga de tan maravillosas herramientas. Por otro lado, si bien no se puede negar la enorme influencia que tienen en la conducta del ser humano y en la forma en que éste se relaciona con los demás, dichos medios no aíslan a las personas; son las personas individualistas que, en busca de una personalización y con una infinita sensación de vacío, quienes deciden conformarse con lo virtual y aislarse. Es clave, pues, cuidar la forma en que las personas se relacionan con cada uno de estos medios: El ser humano debe aprender a servirse de la herramienta y evitar, en lo posible, que la herramienta se sirva de él:

El mouse sirve para abrir, para cerrar; lo utilizo para salvar y borrar.
Con él, achico y agrando, centro y justifico: copio, corto, pego: llevo a cabo una edición.

No sé que me pasa, me siento muy mal; mi mano está adherida al ratón, mi vista es rehén de la pantalla.

Es otro quien se vale de mí para abrir y cerrar puertas; salvar o aniquilar; agrandar o achicar los acontecimientos.

Centrar a la izquierda, justificar a la derecha; copiar, cortar o pegar pedazos luminosos de una realidad fragmentada.

Me han convertido en ratón. Soy sólo un espectador.

Si un niño pasa de seis a nueve horas frente al televisor y si se comprueba que en ese mismo hogar el resto de los miembros de la familia está cada uno en diferente habitación frente al Nintendo o frente al Internet, queda muy claro que no es un problema mediático, sino un problema grave de relación interpersonal: los miembros de dicha familia son incapaces de convivir y de relacionarse.

A quien decida acercarse con la clara intención de servirse de ellos con fines prácticos, de diversión o de cultura, lejos de naufragar, controlarán el timón y serán capaces de llegar con bien a puerto. 
